out considering also its hinterland. Additional tourist and recreational pressures were bound to result from the development of the M6 motorway and it would be vital to relieve congestion on the Lake District; for example, by improving road access around its southern and western edges and opening up parts of the coast that were at present under-used. It was suggested that increased pressures on the Lancashire coast further south might be diverted inland to new recreational schemes; possible recreational schemes were mentioned for Aintree and in the Trough of Bowland.

The conference could not forget that the Cumberland and North Lancashire coasts and Merseyside are all parts of development areas where the Government is encouraging the growth of industry. Among the major changes which could affect parts of the northwest are the 2,400 megawatt nuclear power station soon to be built at Heysham; a $£ 530$ million port development for 100,000 ton ships at Crosby at present being considered; and the Morecambe Bay barragenow the subject of a feasibility study.

Apart from the digest of the conference, the report also contains land use statistics for the 257 miles of coastline in the area and a review of the movement of the retired population in the area. There is also a useful summary map in colour showing the main developed and protected areas along the coast together with some aspects of recreational use. One detail (included with all the other reports, too) is a diagram of the coastal eyesores; pillboxes and other wartime structures, rubbish tips, areas of barbed wire and abandoned barges and other vessels. The Ministry of Defence should be encouraged to take them away.

\section{Computer Hook-up}

THe British Post Office is beginning to consider how its existing Datel service for the transmission of data for computers over telephone and telegraph lines will need to be extended in the future. To this end, a unit is being set up to study data transmission networks, and may have some kind of preliminary report available in nine months to a year's time. Reduced to its essentials, the choice seems to be between improving the Datel system to keep pace with the demands made on it or to go in for an entirely new kind of network. The Datel system itself is based on the existing telephone system, with the addition of units called "modems" at the transmitting and receiving ends, which make the connexion between the line and the data handling equipment. In this way, users can be linked with large central computers and, with the introduction of multiple access machines, numbers of remote users can use the computer in a manner approaching a conversation.

Data transmission in the United States is at present based on the same kind of system as the Datel service in Britain. The difference in the United States is that the American Telephone and Telegraph Company, which runs the system, is allowed a monopoly only so long as it uses the existing telephone system. Otherwise data transmission services would have to be hived off into another company. This means that, to avoid losing the growing data business, the American Telephone and Telegraph Company has to show that the best way of handling data is to exploit the telephone network by adding modems at the ends of the lines.
Because of the Post Office monopoly of communications systems, this problem does not arise in Britain and the Post Office can consider the problem without being influenced by commercial necessity. As it is, the existing system has a number of drawbacks. For one thing, it makes poor use of telephone lines-a system designed purely for the transmission of data could carry more information at a greater speed. Another factor is that up to now the users of multiple access computers have had to be within a few miles of the machine, otherwise the cost of trunk calls makes use of the machine prohibitively expensive.

One of the alternatives which will no doubt be considered by the Post Office study group is put forward by a group at the National Physical Laboratory. This system is aimed at providing the remote user with a rapid response from the computer, so that a conversational type of interaction is possible. The system also uses existing telephone lines but with computers at the intersections of the lines which control the routing of messages and data through the system. This means that every message or block of data in the system carries some indication of its source and destination. Messages enter and leave the system by interface computers, connecting subscribers within a small geographical area to the main network. The advantage of such a system seems to be that it can handle data rapidly, making efficient use of existing telephone lines. The fear that such a system would lead to choking of trunk lines is not justified, according to the National Physical Laboratory. A network such as this linking twenty towns would perhaps cost in the region of $£ 10$ million and have a response time of less than $100 \mathrm{~ms}$.

What is important is that to make the fullest use of computing facilities throughout the country a decision on what form the data network is to take should be made as soon as possible. As it is, a number of separate special purpose networks are already being set up, for the banks and airline bookings for instance, leading to avoidable duplication of facilities. Before this situation gets out of hand, the Post Office must announce its decision on how computer networks are to develop in the future.

\section{More Civil Servants}

Despite the air of uncertainty which has spread through the British Civil Service since the Fulton Commission was appointed to examine it, the Civil Service Commissioners, responsible for recruitment, report a successful year (HMSO, 6s.). In particular, entry to the Administrative Grade, from which the senior civil servants of the future emerge, continued at a high level. There were over 27 per cent more candidates who wanted to join this grade, and 149 were declared successful, against 112 in 1966. Some successful candidates, the report admits, declined appointment, and others preferred to do research work or voluntary service overseas before buckling down to work in Whitehall, but the number who did accept was enough to fill the vacancies.

Another of the commission's preoccupations is to increase the number of applicants who come from universities other than Oxford and Cambridge. Again they are cheerful about progress; in 1966, for the first time, applications from other universities made up 
more than half of the total, and this record was maintained in 1967. In the first quarter of 1968, the other universities seem to be making further gains, with 60 per cent of the applications.

The story in the scientific classes is less encouraging. Posts in the chemical, geological and biological sciences have been fairly easy to fill, but there remain significant shortages, the report says, of mathematicians, physicists and research engineers. This is partly a reflexion of imbalances in educational output, the commissioners think, but they can hardly claim that it does not also reflect the opinions of talented graduates in these disciplines of a career in the scientific civil service. The report also says that "the limited degree of flexibility in determining starting salaries is an inhibiting factor in all cases where demand exceeds supply". In these edgy days before Fulton, this is as near to a direct criticism of the service as the commissioners allow themselves. They are sharper about the universities, however; many of the candidates with higher degrees "do not appear to have derived sufficient benefit from their extended stay at university, and a $\mathrm{PhD}$ is not necessarily a reliable pointer to suitability for the Scientific Officer class". Many of those with thirds and pass degrees, they add, would have been the better for a more practical course of study.

\section{Defence Research}

THE Select Committee on Science and Technology continued its investigation of the British defence research effort by attempting to discover what part the Treasury plays. Some members feel that it is an entirely negative part, and the Treasury representatives who gave evidence on May 23 did not entirely succeed in dispelling this impression.

Briefly, the role of the Treasury is to operate as a financial longstop, examining such things as the defence budget costings, the annual estimates, the staff complements at the Ministries of Defence and Technology and the financial procedures and managerial efficiency of the departments. It also examines and approves (or, presumably, occasionally disapproves) individual research and development contracts. This is done by a group of people which includes no scientists or engineers, but just, as the witnesses put it, "talented administrators". The civil research projects of the Ministry of Technology, for example, are overseen by the Science and Technology Division of the Public Sector Group. With a name like that, one might expect to find some scientists and technologists in the division, but apparently there are none; the witnesses explained that the concern of the division was not to question the technical feasibility of projects, but to supply economic expertise.

Mr Eric Moonman attempted to find out how people were selected for this division. The witnesses said that there were no formal or written instructions. The staff were simply administrative civil servants. Mr Parkyn was concerned that there was no incentive for scientists on defence contracts to save money. If they spent less in a financial year than was budgeted for, the money could not be set aside for the next year, but instead reverted to the Treasury. Did this not encourage extravagance? The witnesses thought not, and suggested that any other system would be much harder to operate.

\section{Parliament in Britain}

by our Parliamentary Correspondent

Flats Collapse

Mr Anthony Greenwood, Minister of Housing and Local Government, gave the membership of the committee which is to investigate the collapse of the block of flats at Canning Town in London. Mr Hugh Griffiths QC would be chairman of the committee, and he would be assisted by Sir Alfred Pugsley, professor of civil engineering at the University of Bristol, and Sir Owen Saunders, professor of mechanical engineering and vice-chancellor of London University. The task of the committee is to "inquire into the circumstances affecting the collapse of the flats at Canning Town on May 16; to ascertain and report the cause or causes; to consider the implications of the findings; and to make recommendations". (Written answer, May 21.)

\section{Heavy Water}

Mr Dickson Mabon, for the Scottish Office, declined to give any directive to the North of Scotland Hydroelectric Board to go ahead with plans for a 200-ton-ayear heavy water plant. Mr Alisdair Mackenzie, who had asked for the minister to issue such a directive, said that the plant would be based on an interruptible power supply. Mr Mabon said that the board was always ready to enter into discussions with any industry which wished to begin operations in the area. (Written answer, May 22.)

\section{Porton}

MR TAM Danyell asked a long series of questions about the Microbiological Research Establishment at Porton. In a series of replies, Mr John Morris for the Ministry of Defence said that Porton had developed a portable resuscitator, a mobile laboratory pathogen unit which was being widely demonstrated, and a needleless injector. It was producing for sale to the WHO an antigen for testing human and monkey serum for evidence of infection with the vervet monkey disease agent, and had a programme of research on decontamination. Information about the work on monkey disease had been widely distributed to forty laboratories all over the world. (Written answer, May 22.)

\section{Planning College}

Mr Alan Wrlliams, Under-Secretary at the Department of Economic Affairs, declined to commit himself on the possibility of establishing a National Planning College, as suggested by the TUC. The Fulton Committee would be reporting in just over a month, and it would be better to wait until then before deciding. Mr Stratton Mills (Con.) suggested that the answers from the Government Front Bench raised grave doubts about whether the planners were fit for their jobs. $\mathrm{Mr}$ Williams retorted by promising that if a planning college were set up, a planning kindergarten would also be set up, for the Opposition. (Oral answer, May 23.)

\section{Hypersonic Flight}

MR Wedgwood BenN, Minister of Technology, said that research on hypersonic flight had been reduced at RAE Farnborough over the past two years. The Plowden Committee had recommended that preference should be given to more modest types of aircraft, and so the research on hypersonic flight had been reduced to a level sufficient to maintain an interest in the field. (Written answer, May 23.) 